\title{
Visual Communication and Consumer-Brand Relationship on Social Networking Sites - Uses \& Gratifications Theory Perspective
}

\author{
Fedric Kujur ${ }^{1}$ and Saumya Singh ${ }^{2}$ \\ ${ }^{1}$ Indian Institute of Technology (ISM), Department of Management Studies, Dhanbad, India, \\ fedrickujur@ms.ism.ac.in \\ 2 Indian Institute of Technology (ISM), Department of Management Studies, Dhanbad, India, \\ saumya@iitism.ac.in
}

Received 30 August 2018; received in revised form 13 December 2018; accepted 7 January 2019

\begin{abstract}
In the present time of web-based social networking, visual communication assume a key job in business and public communication. Social networking with its astute features has the ability to pull in numerous to interface with others. Visual communication plays key role in engagement behavior on social media further adding to sales. The high quality visual improves visibility in Social Networking Sites and are being selected as organization's key activity. Thus, the present study proposes a theoretical model of how visual communications through consumer engagement on corporate Social Networking Sites pages influences the consumer-brand relationship. Structural Equation Modelling has been used and validated the effect of visuals with informative, entertaining and remunerative content on consumer engagement further leading to consumer-brand relationship. Uses and Gratifications Theory has been adopted to study the behavioral response of the customers in relation to consumer engagement in social media context. This is a pioneering work to measure the mediation effect of consumer engagement to check the dominance of mediation (consumer engagement) over direct relationship between independent (visual contents) and dependent variable (consumer-brand relationship) on Facebook. In future similar study may be conducted in other social media platforms.
\end{abstract}

Keywords: Visual communication, Consumer engagement, Social networking sites, Consumerbrand relationship, Structural equation modelling 


\section{Introduction}

With the diffusion of technology innovations in digital photography and online publishing, growth in aesthetic demands has triggered an unprecedented movement in visual communication using various media over the past two decades [10]. In the present age of social media, visual communications are considered as a key ingredient in commercial and public communication. Social media with its interactive features has attracted millions to join Social Networking Sites (SNS) to connect with others. The social media users heavily rely on visual contents to communicate. This can be done by telling stories, entertaining their friends or by sharing their emotions with others [16]. Visual communication can be considered as one of the major tools used to enhance social media engagement, readership and even sales. Phrases like visual content is king or the visual web are powerful key-words in professional blogs, articles and white papers and are promoting visual content as a necessity, not an option [4], [5]. The famous statement, a picture is worth a thousand words holds true when messages that are sent through visual communication on Social Media are appreciated overwhelmingly [70]. But in all seriousness, visuals do carry a lot of power, especially for brands on social media as the elements of visuals allow marketers to create deeper connections with the customers [92]. Since the larger amount of information is available on social media, the users prefer to skip many contents until they find them more attractive and are convinced that it is useful to them. The high quality visual assures visibility in SNS as it is eye-catching and conveys the idea quickly [15], [92].

The visual communication can be used for dissemination of information and ideas using symbols, imagery, signs, graphic designs, films, typography etc. According to the Manic [85], Visual contents can be categorized into three major types:-

1. Illustrations- the composition of static visuals which includes drawings, photos and latest introduced visuals memes. This type of visual contents usually carries a line of text to brief the visuals. Illustrations are usually short in nature and very easy to understand.

2. Comics- the collections of images and text, structured in a proper order with a clear storyline. This type of visual content includes infographics (presentation of large information in a graphical manner) and visual stories. This type of visual is a good storyteller and easily remembered.

3. Videos- the collection of moving images in the form of clips or short films with a clear story and a short message. Videos are a very powerful means of communication to human emotions.

However, various studies have broadly considered only two components of visual content images and videos like photographs, graphics, images or videos [15], [96], [98], [117].

The growing popularity of social networking sites (SNS) such as Facebook, Twitter, Google+, YouTube etc., has lead corporates to establish their social media presence and continuously pursue engaging their potential customers so that they can maintain a friendly relationship with the customers. For this purpose, the corporates are creating their own pages on various social media platforms where brand-related contents could be posted to connect the potential customers. This allows followers to express their opinions in the form of like, comment and share [71], [107]. In SNS, the sharing of visual contents relating to brands are becoming an integral part of the social media activities and this dramatic shift of interests towards visual contents has arguably changed the perceptions of people among themselves and the world around them [117]. Visual content communication is a powerful means to grow the presence of brand on SNSs because it is more influential than text messages [15]. Visuals provide vivid and concrete representations of information and are more accessible to a person's memory which makes processing and recall faster and easier [64]. It can be advantageous for brands in the form of building deeper connections, increasing the believability of marketing efforts and foster communication [92].

Consumer engagement is gaining attention from academia as well as from practitioners, reason being its strategic impetus on developing the rousing relationship between both the parties (business organizations and consumers) to seek mutual advantage in it [86], [87], [121], [127]. The corporate SNS pages have been successful in engaging consumers with their visual contents. Pandey and Sang [96] have noticed in their study that with the increase in the use of mobile cameras, the visual contents has become a prevalent form of online communication on various SNSs. Another study by Manic [85] describes that when visual contents especially images and videos are implemented on the timelines of Facebook, an increase of $14 \%$ in fan engagement, $46 \%$ in content engagement and $65 \%$ in interactive content engagement was observed. Further, Hellberg [52] states in his study that other than well-established SNSs (Facebook and Twitter), Instagram has found huge success with simple feature of sharing images with friends and other followers adding minimal or no text to the posts and has surpassed 300 million users which is larger than twitter's follower base. Due to this fact, $86 \%$ of the world's leading brands have already created account in this platform to get high exposure [52], [113].A blog by Pollard [100] states that when visual contents are uploaded on brand SNS pages on Facebook, it generates 53 percent more engagement with their audience than a text-based post. According to one study tweets having visual images are able to receive $18 \%$ more clicks, $89 \%$ more favorites and $150 \%$ more retweets [22]. Further, Kimball [70] reveals in his study that more than 30000 Facebook brand pages possessing images are able to gain more popularity. Even, visual images used in social media are more likely evoke emotional reactions in 
viewers and can portray information more efficiently than text [100]. Thus, visual content is vital to build company/brand engagement. Moreover, a blog by More [88] describes three important reasons for driving engagement through visual contents. They are (i) it communicates information quicker and more efficiently, (ii) it builds trust, (iii) it is easy to engage with.

Social media is gaining importance as a channel for consumer engagement. Diverse resources are being invested in social media and brands from all over the world to continue to grow their online fan base and engage them in brandrelated online activities [23], [30], [107]. The engagement over SNS contributes immensely to the field of marketing. High consumer engagement leads to popularity of the social media advertisements [25], strengthening consumer-brand relationships through timely interactions and exerting positive attitude towards the company and brand [43], [122]. Despite the growing number of research in consumer engagement with brand on SNSs, its operationalization is highly fragmented and has several shortcomings. Initially, the studies focused on investigating consumer activities and brand communications by examining content posted/uploaded on the brand SNS pages and found drivers that gives a momentum to the customers towards usage of social media [121], [122]. Even the recent studies have primarily focused on consumers' response to social media advertising by exploring motivational factors driving consumer engagement with brand SNS pages [115], [116]. The motivating factors of consumer engagement attempted to measure only the strength of engagement, however, it ignored the nature and forms of behavior portrayed for consumer engagement with brands present on SNSs. In order to address this literature gap, the study has followed the Consumers' Online Brand-Related Activities (COBRA) firstly introduced by Shao [109] and later extended by Muntinga et al. [90]. The COBRA framework is an umbrella behavioral construct that encompasses the consumer activities relating to brandrelated content on social media.

According to Cvijikj and Michahelles [23], the visual contents can be divided into three forms namely informative, entertaining and remunerative content which were found to be the important drivers of online engagement in terms of likes, comments, and shares. A study by Muntinga et al. [90] disclosed that these three factors of visual contents are the important drivers of the engagement in social media and online brand-related activities in the form of consumption, contribution, and creation. Various researchers put stress on information seeking, entertainment, incentive including social interactions as the main motivators for using SNS and active participation with brand-related activities [24], [63], [67], [72], [75], [128], [111]. Thus, the present study can be considered as one of the opening attempts to analyze the influence of visual contents on engaging consumers in online brand-related activities in the form of consumption, contribution, and creation.

Several studies in marketing literature have theorized the concept of consumer engagement as a significant practice in building competitive brand advantage and shaping consumer-brand relationships particularly in social media environment [13], [29], [34]. An empirical study by Tsai and Men [122] shows that the behavioral dimensions of engagement construct such as consumers' brand-related activities results in establishing consumer-brand relationships Although several conceptual and exploratory works have shown role of consumer engagement in establishing organization-customer relationships but still existing literature don't give a complete overview of the process and consequences of the consumer engagement with organizations [14], [57], [124], [127]. In addition to it, Hollebeek et al. [58] and Dessart, [29] have also pointed out the scope of further research in contribution of consumer engagement in developing customer-brand relationship and to be validated in social media environment. The present study is an attempt to throw light on the way social media engagement behavior can transform individual consumer predispositions into beneficial brand outcomes.

The present study emphasizes role of visual communication in generating engagement with brand-related content in social media pages which further builds consumer-brand relationship. Visual communication is powerful in drawing attentions and is capable of stimulating visceral responses and inciting emotions, ultimately leading to change in attitudes and behaviors. However, brands are facing challenges in connecting with their audience online as the amount of information available for audience is huge due to large number of people and businesses posting their contents on SNSs. This flood of information compels organizations to compete for attention. Therefore, the study on the visual communication is imperative for generating engagement with social media visual content. Previously, research on the effectiveness of narrative messaging [50] and text-based engagement [69] have already been conducted in the academics whereas little research has explored the impact of leveraging visual content to generate engagement. Thus, the present study proposes a theoretical model of how visual communications through consumer engagement on brand SNS pages influences the customer-brand relationship. In order to explain this theoretical model, Uses and Gratifications theory (UGT) has been applied to support the present study. The UGT has already been adopted by few researchers to study the behavioral response of the customers in relation to consumer engagement in social media context [23], [24], [33], [72].

\section{Literature Review}

The dynamics of consumer engagement on social media has resulted in rapid sectoral changes of far reaching magnitude. Usage of social media as a convenient tool to promote their product and services has given a new orientation to the marketers. The present study has followed the Uses and Gratifications Theory (UGT), to lay its theoretical foundation, developed by Psychologist Herzog [54] to understand why people actively look for specific media to satisfy specific needs. The UGT was initially applied in various traditional mass media (such as television and 
electronic bulletins) to analyze the motivation and associated behaviors of being engaged in various forms of media. However, with the invasion of internet and new technologies, the UGT focused on the prerequisite motivations for people to use the new and modern technologies to make more informed and better decisions. Moreover, this theory is being significantly applied on the social media studies as the audiences are playing roles in choosing and using the media/applications that provide platforms for interactions [33], [62], [84], [94], [114]. This theory is based on two assumptions, (i) the consumer is an active and self-conscious contributor in media choice; (ii) the consumer is driven by social and psychological needs and therefore, seeks out a media that could fulfill his goals. The level of gratification received by the consumer determines the recurring use of that particular media [62], [72], [78]. The theory divides consumer's needs in five classes namely: cognitive needs, emotional needs, personal integrity needs, social integrity needs, and tension release needs, that would influence the uses and gratifications of a media [111]

The use and gratification theory has been applied in the context of social media by various studies, to explore the motives of using SNS [67], [111], [128] to identify various factors motivating consumer engagement with brand pages on SNS [24], [33] to examine social media content for achieving more consumer engagement online [23], [72] and to analyze factors motivating mobile advertising through various social media platforms [81], [131]. This theory also has been used for developing models and hypotheses by exploring motivational factors influencing positive engagement behavior [27]. From the previous literature it is evident that how this theory has been applied to gratify the emotional, cognitive and other emerging needs of the consumers in choosing and using technological media and thus attract viewership of consumers. Based on this logical concept, the use and gratification theory fits well with the present study as it aims to investigate the influence of visual communications on consumer engagement with brands on SNS.

\subsection{Visual Communication}

The research on visual communication has already been carried out in various disciplines like communication, psychology, art and science etc. due to its wide applicability in different domains [52]. Since the visual communication transmits the information and ideas by using symbols and imagery, it can affect the viewers either affectively (emotionally) or cognitively (logically) or both reactions simultaneously [52], [39]. According to Sharma et al. [110], the $75 \%$ of all information processed in human brain is from visual communication. Further, they attempted to explain the system of visual processing and the implications of how the visual system functions. When information is conveyed through images through a particular medium, the viewers' brain processes the images and then interprets and understands through personal filters which are made up of personal experiences, cultural and social backgrounds as well as attitudes. Previous studies have shown that visual advertisement with more information and without any cognitive load are found to be more persuasive than verbal advertisement as it conveys large information instantly [89], [110]. However, the combination of both visual and verbal communication seems to get best responses from the viewers [117]. In addition to it, the effect of visual communication is essentially connected to individuals' personal inclination which further influences consumer behavior, attitude, and recall [108]. Therefore, the study of visual communication is essential in the realm of social media, especially the analysis of the visual contents which induces reactions among the viewers.

Visual content in advertising has always been associated with consumer engagement and this has been even accelerated with the diffusion of technology innovation in social media. Visual content is used as one of the best strategy for stimulating online engagement [57]. According to Sashi [104], the effective engagement can be achieved by creating persuasive content. As colossal information are available on SNS it becomes time consuming for the viewers to go through all and they prefer messages with visual contents to save time. According to Kimball [70], SNS like Facebook or microblogging sites like Twitter have changed the way of giving information to people online by enabling shorter pieces of content. Due to this emerging trend, blogging by U.S teens has been declined dramatically between 2006 and 2010. Since visuals are consumed and shared with others the most, it has led to the rise of various SNS such as Facebook, YouTube, Instagram, Pinterest, Snapchat, Tumblr etc. By engaging consumers with visual contents can drive awareness and lead engagement and strengthening the bond between brand and customers [12]. Moreover, the continuous interactions with brand help to understand like and trust in the brand [55].

\subsection{Consumer Engagement with Brand-related Content}

Recently the use of social media has led to the rapid emergence of customer engagement and has increased attention in both practice and research. Customer engagement refers to the emotional connection between a customer and a brand which is subjected to the level of consumer's involvement in products' purchase, interaction done on Social Media, intimacy between the consumers with the brand and influence over a period of time [103]. A definition given by Brodie et al. [14] states that consumer engagement is a multidimensional concept consisting of cognitive, emotional, and/ or behavioral dimensions, and involves interactive experiences between consumers and the brand, and/ or other members of the virtual brand community. Further Hollebeek et al. [59] defined consumer engagement as a consumer's positively valence brand-related cognitive, emotional and behavioral activity during or related to focal consumer/ brand interactions. Vivek et al. [127] defines Consumer Engagement as the intensity of an individual's participation and connection with an organization's offerings and/ or organizational activities, which either the customer or the organization initiate. From the above definitions, two things can be noted about consumer engagement that is the importance of multidimensionality and relational exchange nature of the construct which states behavioral manifestations that have a brand or firm focus, beyond purchase, resulting from motivational drivers [30], [61]. 
In social media context, the research on consumer engagement has received high attentions of academicians, managers and practitioners [83], [104]. Many authors like Brodie et al. [14], Hollebeek et al. [58] and Dessart [29] have emphasized the need of more research on consumer engagement in SNS in order to fill in the existing knowledge gap in the literature. From the prior research, it has been noticed that more focus has been given on identifying factors that drive motivations for consumer engagement and how they impact consumer's intended behaviors. Nowadays, consumer engagement is a multi-dimensional construct which includes cognitive, emotional, and behavioral dimensions. However, few studies have shown that the multi-dimensional construct of consumer engagement such as cognitive and emotion make it difficult to measure consumer's level of engagement as it is directed to measure only the strength of engagement, while ignoring the nature and specific types of engagement behaviors with brands in SNSs [95], [133]. Therefore, the present study has focused on contribution of customer engagement in behavioral manifestation. Behavioral manifestation explains about the extent to which customers engage in different online behaviors [9], [124]. Muntinga et al. [90] defines three specific types of engagement behaviors namely consuming, contributing, and creating activities which are crucial factors to measure the consumer engagement when visiting brand pages on SNS. The rise in the use of social media and new technology is directly influencing engagement behaviors as these platforms facilitates interactions between people and the firm or brand. So far, there are few empirical studies on customer engagement behaviors, in general, and particularly in social media, although customer engagement has been recognized as key research priority of the Marketing Science Institute [9], [95], [121], [122], [133]

In view of the above explanations, it necessitates the requirement to measure the extent to which the consumers are engaged with corporate SNS pages and to explore the nature and specific type of engagement behavior, which also have important consequences for the firms, products and brands. Consumer engagement behavior is becoming influential as viewers prefer to have informal and interactive feedback of other users than formally designed company's information. Muntinga et al. [90] classified consumer's online brand-related activities (COBRA) into three categories, i.e., consuming, contributing and creating. They are the significantly distinctive behavioral patterns which are divided on the level of activeness of social media use towards brand-related activity. The consuming behavior of consumer represents a relatively passive type of online participation and a minimum level of online brand-related activeness on SNSs. Consumers falling under this category only watch videos and pictures, read product reviews and download brand widgets without active participation. Another category which represent contributing behavior, possess comparatively higher degree of involvement towards online brand related activities. They are involved in giving responses on social media, remain engaged in wall post conversations and comment on videos and other interactive content. The creating behavior of consumer represents the ultimate level of online brand-related activeness. They are the contributor of user-generated content (UGC) which may involve posting user's own product reviews and publishing and sharing videos and pictures on brand SNS pages. Due to the high degree of involvement of this group their recommendations may be considered trustworthy for the other two categories of consumers.

From the above discussion, it is clear that visuals do influence consumer engagement but it is still unclear which type of visual contents are effective in drawing attentions of the social media users. In the previous literature, visual contents have been studied for various purposes like measuring brand post popularity [23], [25], [119], engaging consumers with brand related activities on corporate SNS page [80], identifying motivations for using social media websites [14], [69] and so on. Further, visual contents have been divided into three types namely informative content, entertaining content, and remunerative content [23]. These visual content types are based on the purpose of delivery of the messages on SNSs. For example, the purpose of visual communications can be either to deliver information or entertainment or remuneration, it all depends on the communicator who communicates for what purposes. In the context of visual communications, very few studies have been done as to what extent visual contents influence consumer engagement in social media environment [17], [77]. Thus, the present study has taken three visual content types namely informative, entertaining, and remunerative content. Based on this content type, consumers have been asked their preference which engages them the most in terms of consumptions, contributions, and creations.

\subsubsection{Informative Content}

Information seeking in the social networking sites is the key construct among the peers as they perceive or experience the product or the brand or the company useful and enjoyable [79]. The previous studies reveal that the pleasureoriented information system makes social effects and motivates to participate and to contribute to brand communities in the SNS [31], [97]. Research also states that when visual contents are used, it conveys a lot of information quickly and easily to the readers than the plain text. A number of media like videos, slideshows, graphs, charts, and infographics can be used to condense the information to the social media users, as they are more attractive, appealing and user-friendly and tend to get more clicks, tweets and retweets [117]. Hence visual post containing brand related information also works as the key motivational factors to create interaction with and to engage consumers with brandrelated activities (like, comment and share) in SNSs. Further research shows that since the consumers are provided with useful information, they tend to have positive attitudes toward informative ads on SNS [25]. Thus information in the content motivates the consumer engagement in SNS.

H1: Visual contents with brand information encourages consumers to engage with brand-related activities on corporate SNS page. 


\subsubsection{Entertaining Content}

The important motivational factors for the consumer participation in SNS depend upon consumers' interest to experience entertaining content in the brand post. Enginkaya and Yilmaz [38] points out that entrainment factor are novel characteristics for social media brand engagement literature. Various others studies have also considered the entertaining value to measure the level of consumer engagement using visual posts like images and videos on brand SNS pages, as it involves high levels of pleasure and arousal while viewing or watching an advertisement [76]. This high level of pleasure and arousal further influences consumers' intentions to return to social media and also influences the desire to spread positive WOM about the brand [33], [102]. Muntinga et al. [90] also found the entertaining value or content as the main motivating factor for online engagement which was utilized in the form of consumption, contribution and creation. The visual content-driven characteristics of advertising message that is entertaining has been identified as determinant influences on consumers' attitudes toward the brand post on brand fan pages [25], [120]. Thus entertainment in the content motivates the consumer's online engagement in SNS.

H2: Visual contents with entertaining value encourages consumers to engage with brand-related activities on corporate SNS page.

\subsubsection{Remunerative Content}

Remuneration is something that motivates an individual to perform an action. According to Chua and Banerjee [20], the provision of remuneration encourages the social media users to participate and engage in the brand-related activities like liking, commenting and sharing of the brand post in SNSs. People who are influenced by the remuneration tend to join brand forums, online communities and brand pages on different SNSs and comment on blogs, pictures, videos etc. [90]. Many studies have witnessed that most of the brand posts uploaded in the brand SNS pages consist of visuals like images and videos [20], [81]. The content driven by remunerative characteristics also influences the attitude of the consumers towards the brand post [23]. Further, Chua and Banerjee [20] explain different types of incentives that help in engagement and participation. Few examples of different incentives are monetary incentives, incentive for specific software through participation in open software development, job related incentive and so on. Based on the above findings in the context of visual brand post containing information relating to brand incentive are more likely to draw users' attention compared with those that do not. Moreover, the visual content driven by remunerative characteristics also influences the attitude of the consumers towards the brand post [23]. Thus, visuals with remunerative content motivate the consumer's online engagement in SNS.

H3: Visual contents containing information relating to brand remuneration encourages consumers to engage with brand-related activities on corporate SNS page.

\subsection{Consumer-Brand Relationships}

The root of business survival is the consumer. Therefore, establishing a good relationship with the consumers for any business organizations is very essential [13], [34], [127]. The strategies for building and maintaining quality relationships with the consumers have garnered much attention from customer relations practitioners and theorists during the past decades [53], [66]. The concept of organization-customer relationships is one of the major outcomes of customer relations. In the present scenario, the customer relationship management (CRM) is applied extensively by the business organizations to serve essential needs of customers proactively, promote transparent dialogue and improving the efficiency of customer interactions, increase research and development capabilities, and frame customer focused strategy, to gain competitive advantage. According to Egan [37], the concept of relationship building has become global concern in many industries around the world. The core ideal relationship building involves long-term collaborations in which both the parties actively participate and take benefits [48]. Ferrand and McCarthy [41], rightly points out that the relationship arise through the interactions between both parties and involve mutual exchanges serving the goals of all involved. As such, every interaction between each customer and the organization serves to build relationships [84]. From the last decade, interactions through social media have gained popularity among the business organizations so as to work collaboratively with customers to meet shared goals through communication, feedback, and engagement. Further, the previous literature shows that quality of relationship is measured or evaluated in terms of reciprocity, trust, credibility, mutual legitimacy, openness, and long-term commitment [46], [74]. Later Hon and Grunig [60] by using interpersonal relationship theories identified six relationship parameters which are widely adopted they are trust, control mutuality, satisfaction, commitment, exchange relationship, and communal relationship. Among these parameters, trust satisfaction, and commitment have been already considered as a measure of quality relationship [87], [123]. Therefore, in the present study these three parameters have been selected to measure the relationship quality between the organizations/brand and customers.

\subsubsection{Trust}

As per Swann and Gill [118] customers do not have much experience with the company in the beginning of their relationship with the company. Reason behind this may be the limited connect due to their little exposure to the company's real information. Therefore, by creating SNS pages companies are posting continuously brand or company related information to increase their visibility and reach among the SNS users, so as to create perceived trustworthiness of the organization [44]. According to Hon and Grunig [60] trust is a very essential parameter of measuring relationship 
as it shows the level of confidence and willingness to open oneself to other party. Further, their study also divides trust into three dimensions namely integrity, dependability, and competence, which strengthens trust factor in the mind of customers. The recent study by Vivek et al. [127] also states that trust is an important factor acting as a relational governance mechanism assuring partner reciprocity and non-opportunistic behavior. In addition to it, when customers engage with brand-related activities on SNS, they develop a feeling of trust with the company/brand which further strengthens the bond of relationship between them.

\subsubsection{Satisfaction}

Verhoef et al., [125] state that satisfaction is a state of emotional experience which arises with the evaluation of interaction experiences. As per the definition given by Anderson et al. [2] satisfaction refers to the evaluation of total purchase and consumption experience with a good or service over time. It may be for this reason; satisfaction is always linked with value offered services for which the satisfied customers tend to behave in a manner that is valuable to the organization. Previous literatures have also supported that the positive effect of satisfaction results in customer referrals, purchase intentions, usage of a service, and relationship duration [8], [132]. Even Men and Tsai [86] also point out that favorable feelings for any organizations are developed from positive expectation of relationships. It remains valid in social media environment too when Gummerus et al. [47], Brodie et al. [14] and Hollebeek et al. [59] define brand satisfaction as an outcome of consumer engagement as it facilitates consumers and brands interactions on this media. The process of engagement with brand related activities could gradually trigger higher levels of confidence fostering brand satisfactions and there by strengthening the consumer-brand relationship.

\subsubsection{Commitment}

Commitment is the state or quality of being dedicated in which two parties desire to strengthen a relationship. According to Verhoef et al. [125], there are two types of commitment namely affective commitment and calculative commitment. Affective commitment refers to the psychological attachment a customer has for an organization which is based on feelings of identification, loyalty, and affiliation [127]. On the other hand, calculative commitment refers to desire to continue relationship due to given anticipated termination or switching costs associated with leaving. Later on, the calculative commitment is replaced with continuance commitment referring to the commitment to continue a certain line of action [86]. Brodie et al. [14] and Hollebeek et al. [59] indicated brand commitment as the outcome of consumer engagement in social media context. Interactive features of social media enables consumer's emotional and psychological attachment and preference for a brand leading to consumers' commitment that subsequently strengthen the consumer-brand relationship.

\subsection{Communication and Consumer-Brand Relationship}

A host of studies have considered visual communication as the antecedent of consumer engagement while describing the importance of social media in building and strengthening relationship [6], [15]. Though none of the studies have considered visual communication as the direct antecedent of consumer-brand relationship in the realm of social media research, a chunk of studies do acknowledge that visuals have strong impact on the relationship building mechanism through engagement process with the social media content [45], [64]. Creating an attractive visual content can enhance strong relationships between brand and customer [45]. A successful content marketing strategy needs to build and strengthen relationships. Relationships provide a wealth of content and provide the opportunity to cross-pollinate the target audience. A visual content with high quality is considered as the currency for building relationships that can boost credibility, influence and action. To the best of our knowledge, the present study is the first attempt which considers consumer engagement as a mediator while examining the effect of visual communication on consumer-brand relationships. However, few studies have already considered consumer engagement as a mediator while measuring the level of influence on consumer-brand relationships [106], corporate reputation [42] and consumer purchase intention [62]. Hence, philosophical underpinnings grounded on the argument of transitivity assumes the role of visual contents as a direct antecedent of consumer-brand relationship while investigating their relationship with respect to social media environment. The basis of inclusion of visual contents is that the axiom of transitivity is regarded as one of the basic principles of consistency based on the concept of rationality and plays a cardinal role in practical reasoning [126]. Based on the above observations, the present study has assumed that visual contents may have direct relationship with the consumer-brand relationship. Further, this study also intends to measure the mediation effect of consumer engagement to check the dominance of mediation (consumer engagement) over direct relationship between independent (visual contents) and dependent variable (consumer-brand relationship).

\subsection{Customer Engagement and Consumer-Brand relationship}

In establishing consumer-brand relationship, Social exchange theory plays a crucial role as it involves two-way communications. Bortree [11], states in his study that the higher the rate of interactions or engagement with an organization, the stronger the relationship with the customer will be. Visual contents related to a brand on its SNS pages draw the attentions of the social media users and engages them with its interactive features in the content. The frequent and healthy exchange or interactions with content in SNS, brings both the parties closer and fosters a lasting relationship. Clavio and Walsh [21] states that Facebook leads to more interactive experiences with its high quality visuals than Twitter which enhances effective relationship building. Consuming visual contents on corporate SNS page is more important than predicting user's ability of consumption because engagement leads to prosocial relationship 
between organizations/brand and users [16]. Nammir et al. [91] also shows in his study that customer engagement significantly contributes to constructive relationship. Although social media has been very popular platform for the consumer engagement and relationship building, but very few studies have paid attentions to the influence of consumer engagement on consumer-brand relationship building [86], [48]. Therefore, the present study has focused much on how consumer engagement through consuming, creating, and contributing to visual contents, influences the consumerbrand relationship. Thus, the proposed hypothesis would be:

H4: Consumer engagement with brand on corporate SNS pages positively influences consumer-brand relationship building.

\section{Research Methodology}

This section provides a complete overview of the research approach designed to meet the objective of the current research. The research approach includes the need and scope of the research, research framework, research process, research design, questionnaire development, process of sample selection, and the strategy used for data collection and analysis. This chapter presents the results and statistical analysis as per the objectives of the study. The analysis part deals with the Structural Equation Modelling (SEM) approach incorporating a series of qualitative and quantitative analysis. The data analysis includes factor analysis to identify factors affecting consumer engagement, assessment of the fit of measurement model and assessment of the fit of structural model and hypotheses testing.

\subsection{Research Questions and Method}

Increasing use of social media and rising consumption of visual communication in social media platforms by corporates to engage their audience is at its peak. Corporates intend to keep their audience informed about their products and services through their content and maintain a good relationship. The present study seeks to answer few questions such as; to bring forth the significance of visual communication and consumer engagement in social media environment; to explore various types of visual contents that influence consumer engagement in brand SNS pages; to check the effect of visual communication on the relationship building mechanism between corporates and their audience through engagement process. In order to answer these research questions, a conceptual model has been proposed which identifies the types of visual contents and measures their influence on consumer engagement on brand SNS pages and then checks the response of engaged consumers whether the engagement process has any influence on consumer-brand relationship building.

To test and validate the conceptual framework, the research methodology section has been divided into two parts: (1) the procedure for data collections, and (2) the procedure for the data analysis. The procedure for data collection consists of identifying study population, determining eligibility criteria for selection of study population and sample size. On the other hand, for data analysis, the study applied a SEM approach incorporating a series of qualitative and quantitative analysis.

\subsection{Sample Selection and Data Collection}

For the study, young adults of 18 to 29 years were considered as main respondents from different educational institutions located in India. The respondents were mainly representing undergraduate, post graduate and Ph.D. students considering internet adoption and usage rate is highest among young adults whose age were between 18 to 29 [56]. A number of previous studies have identified generation $Y$ (young adults) as the main users of innovative online technological gadgets and communication devices such as mobile applications and Social Networking Sites (SNS), which consequently exposes them to the world of digital/online marketing [32], [49], [120]. Due to this reason, several other studies have considered students as the primary users of SNS and the target market for the online marketers [65], [105]. Furthermore, with the advancement of information and technology communication, it has become a way of life for the students of this age, who are prone to engage more in mediated social interactions, which makes them key targets for viral advertising campaigns on SNS such as Facebook [28], [36], [93]. Students sample are likely to spend more time on the site daily than any other category of users having an SNS account [19]. Thus, a college student sample, representing the largest segment of the SNS user population, is appropriate for this study. Facebook was chosen as a study medium because Facebook has the maximum users in India reaching 142 million and out of which 69 million users are active on daily basis, while 64 million users are on mobile [68]. Facebook is also considered as the world's most viewed SNS with its 972 million regular users in January 2013 [99].

The questionnaire for this study was taken from the previous literatures and was modified slightly to fit in the context of this study. The present study classified items of questionnaire on five-point Likert scale, ranging from strongly disagree to strongly agree. Since the present study intends to measure the intensity of consumers' opinion on the influence of visual communication on consumer engagement, the use of Likert scale fits best in the study. Likert-type scales are useful when you are measuring latent constructs - that is, characteristics of people such as attitudes, feelings, opinions, etc. As the questionnaire adopted in the study were mainly scaled in five Likert scales, the present study used five point Likert scale to check the comparability and consistency with the previous ones. The other reason for using five point Likert scale is that it makes it easier for the people (respondents) to stay focused on the questionnaire and enables 
them to respond honestly. The data was collected using online mode through structured questionnaire. For identification of survey pool, the students of various Indian universities were contacted personally or through phone. After getting positive response link for the questionnaire was shared among them through email. The total time taken for data collection was around two months. The potential respondents of this study are users who are following at least three brand pages on Facebook. Each of them were asked to provide contact information of 10 to 20 individuals and encouraged to include individuals from all range of age groups. These individuals then were contacted and prescreened by being asked the following question: Do you use Facebook? The respondents who answered no were thanked and removed from the respondent list. The respondents who answered Yes were asked again the following question: Do you follow any Facebook brand pages? The respondents who answered no were thanked and removed from the respondent list. The respondents who answered Yes were provided with the study questionnaire and asked to complete the questionnaire over two week period and return it to the researcher. The eligible respondents were briefed about the visual contents, its meaning and types of contents it includes, so that their concept about visual content is clear for this survey. No such incentives were provided to the respondents as the research was conducted for the academic purpose.

The collected data were screened and removed all the miscoded, incomplete and suspicious-looking data entries and finally considered only 430 survey questionnaire for the present study. The collected data revealed 294 men (68.37 percent) and 136 women (31.63 percent). The average age of respondents was 23.5 years, with 20.93 percent at 18 to 20 age group; 36.05 percent at 21 to 25 age group; 43.02 percent at 26 to 29 age group and spend 2-3 hours daily on Facebook activities.

\subsection{Measurement Model}

To test our framework, the study applied a SEM approach incorporating a series of qualitative and quantitative analysis. First, the study analyzed measurement model and then structural model. For the construct validity of the items, we conducted factor analysis. Exploratory factor analysis was conducted using varimax rotation, to reduce large number of variables into a smaller set of interpretable underlying factors. After that the study analyzed measurement model by a maximum-likelihood estimation procedure using AMOS version 18. To assess the model fit, Chi- square (X2); normed fit index (NFI); comparative fit index (CFI); root mean square residual (RMR); and root mean square error of approximation (RMSEA) were considered in this study [7]. The statistical significance of parameter estimates was measured using t-values greater than 2 .

The participants answered a total 31 survey questions. Exploratory factor analysis was conducted which resulted in eight factors explaining $88 \%$ of the variance. See table 1 . Two items relating to contributing in the consumer engagement section was removed as the rate of response was very poor. Then the measurement model fit test was done. Since the RMSEA and RMR was more than .05 and .08, the present measurement model could not fit. Therefore the modification fit index was used to correlate the error terms of the latent constructs to bring the model fitness. The confirmatory factor analysis supported the exploratory factor analysis. The fit of the measurement model was acceptable $(\mathrm{X} 2=876.675, \mathrm{NFI}=0.952, \mathrm{CFI}=0.969, \mathrm{RMSEA}=0.047$, and $\mathrm{RMR}=0.027)$.

Table 1: Results of factor analysis and reliability

\begin{tabular}{|c|c|c|}
\hline Constructs & $\begin{array}{c}\text { Factor } \\
\text { Loadings }\end{array}$ & $\begin{array}{l}\text { Cronbach's } \\
\text { Alpha }\end{array}$ \\
\hline Information [18], [26] & & .856 \\
\hline $\begin{array}{l}\text { INF1- Visual contents are very valuable and convenient source of information } \\
\text { about brands }\end{array}$ & .864 & \\
\hline INF2- Visual contents tells me which brand has the features I am looking for & .785 & \\
\hline $\begin{array}{l}\text { INF3- Visual contents helps me keep up to date about products available in the } \\
\text { marketplace }\end{array}$ & .830 & \\
\hline INF4- Visual contents supplies relevant product information and price news & .852 & \\
\hline Entertainment [18], [26] & & .881 \\
\hline $\begin{array}{l}\text { ENT1- Visual contents gives me pleasure while watching or reading on Facebook } \\
\text { brand pages }\end{array}$ & .818 & \\
\hline $\begin{array}{l}\text { ENT2- Visual contents are even more enjoyable on Facebook brand pages than } \\
\text { websites }\end{array}$ & .857 & \\
\hline ENT3- Visual contents make me feel good & .831 & \\
\hline ENT4- Visual contents are fun to watch or read & .894 & \\
\hline Incentive [81], [26] & & .803 \\
\hline $\begin{array}{l}\text { INC1-Visual contents with monetary rewards (e.g., coupons, discount) attract my } \\
\text { attentions instantly. }\end{array}$ & .897 & \\
\hline $\begin{array}{l}\text { INC2- Visual contents with monetary rewards motivate me to pay close attention } \\
\text { to it. }\end{array}$ & .880 & \\
\hline Consumer Engagement [121], [130] & & .915 \\
\hline \multicolumn{3}{|l|}{ Consuming } \\
\hline CONS1- When I see visual ads on br & .877 & \\
\hline
\end{tabular}




\begin{tabular}{|c|c|c|}
\hline \multicolumn{3}{|l|}{ Table 1: continuation } \\
\hline $\begin{array}{l}\text { CONS2- When I see visual ads, I tend to read reviews or comments of others and } \\
\text { rate it }\end{array}$ & .863 & \\
\hline \multicolumn{3}{|l|}{ Contributing } \\
\hline $\begin{array}{l}\text { CONT1- When I see visual ads, I take active participation by liking and } \\
\text { commenting on it }\end{array}$ & .864 & \\
\hline CONT2- When I see visual ads, I usually share it with my friends & .858 & \\
\hline \multicolumn{3}{|l|}{ Consumer-brand relationship [60] } \\
\hline Trust & & .813 \\
\hline TRU1- This brand treats people like me fairly and justly & .847 & \\
\hline TRU2- This brand can be relied on to keep its promises & .732 & \\
\hline $\begin{array}{l}\text { TRU3- I believe that this brand takes the opinions of people like me into account } \\
\text { when making decisions }\end{array}$ & .780 & \\
\hline TRU4- I feel very confident about this brand skills & .800 & \\
\hline TRU5- This brand has the ability to accomplish what it says it will do & .549 & \\
\hline Satisfaction & & .717 \\
\hline SAT1- I am happy with this brand & .607 & \\
\hline SAT2- Both the brand and people like me benefit from the relationship & .625 & \\
\hline SAT3- Most people like me are happy in their interactions with this brand & .705 & \\
\hline $\begin{array}{l}\text { SAT4- Generally speaking, I am pleased with the relationship this brand has } \\
\text { established with people like me }\end{array}$ & 666 & \\
\hline SAT5- Most people enjoy dealing with this brand & .767 & \\
\hline Commitment & & .862 \\
\hline $\begin{array}{l}\text { COM1- I feel that this brand is trying to maintain a long-term commitment to } \\
\text { people like me }\end{array}$ & .807 & \\
\hline $\begin{array}{l}\text { COM2- I can see that this brand wants to maintain a relationship with people like } \\
\text { me }\end{array}$ & .918 & \\
\hline COM3- There is a long-lasting bond between this brand and people like me & .700 & \\
\hline COM4- Compared to other brands, I value my relationship with this brand more & .610 & \\
\hline COM5- I would rather work together with this brand than not & .896 & \\
\hline
\end{tabular}

To develop and test theoretical models the ability to validate formative measurement is growing and is applicable in multiple disciplines [129]. Hair et al. [51] suggest that while doing CFA, convergent and discriminant validity which are considered as subcategories or subtypes of construct validity, should be conducted to establish construct validity and reliability. They also suggest criteria for acceptance of convergent and discriminant validity. They are as follows:

Reliability $=\mathrm{CR}$ (Composite Reliability) > 0.7;

Convergent Validity=AVE (Average Variance Extracted) $>0.5$;

Discriminant Validity= Square root of AVE greater than inter-construct correlations. See table 2.

Table 2: Convergent and Discriminant validity and Inter-construct correlations

\begin{tabular}{|l|l|l|l|l|l|l|l|l|l|l|l|}
\hline SN & Constructs & AVE & CR & 1 & 2 & 3 & 4 & 5 & 6 & 7 & 8 \\
\hline 1 & Information & 0.83 & 0.92 & $\mathbf{0 . 9 1}$ & & & & & & & \\
\hline 2 & Entertainment & 0.81 & 0.89 & 0.26 & $\mathbf{0 . 9}$ & & & & & & \\
\hline 3 & Incentive & 0.71 & 0.84 & 0.29 & 0.31 & $\mathbf{0 . 8 4}$ & & & & & \\
\hline 4 & Consuming & 0.64 & 0.81 & 0.15 & 0.26 & 0.3 & $\mathbf{0 . 8}$ & & & & \\
\hline 5 & Contributing & 0.72 & 0.85 & 0.23 & 0.3 & 0.29 & 0.42 & $\mathbf{0 . 8 5}$ & & & \\
\hline 6 & Trust & 0.52 & 0.83 & 0.1 & 0.37 & 0.21 & 0.27 & 0.34 & $\mathbf{0 . 7 2}$ & & \\
\hline 7 & Satisfaction & 0.76 & 0.86 & 0.16 & 0.19 & 0.23 & 0.18 & 0.15 & 0.33 & $\mathbf{0 . 8 7}$ & \\
\hline 8 & Commitment & 0.64 & 0.85 & 0.25 & 0.11 & 0.12 & 0.24 & 0.19 & 0.22 & 0.35 & $\mathbf{0 . 8}$ \\
\hline
\end{tabular}

\subsection{Structural Model}

For hypotheses testing Structural Equation Modeling (SEM) was applied using a two-step latent variable modeling approach. Consumer engagement and consumer-brand relationships in the structural model were specified as latent variables and factors relating to visual contents like information, entertainment and incentive were considered as observed variables. Apart from the chi-square statistic $\left(X^{2}=944.23, p<0.001\right)$, all fit indices indicated a good fit with the data $(\mathrm{NFI}=0.95, \mathrm{CFI}=0.96$, RMSEA=0.053, RMR=0.49). The proposed model developed displays the results of the structural model analysis, including significant standardized path coefficients. All structural paths demonstrated significant results (See Figure 1).

The result revealed that visual contents like information, entertainment and incentive were found to have positive influence on the consumer engagement with corporate SNS page. Information showed positive impact on consumer 
engagement $(\beta=0.27, p<0.05)$, supporting $\mathrm{H} 1$. This implies that visuals with more information play a vital role in engaging social media users as they intend to seek more details about the company or brand. Similarly, visuals with entertainment content also showed positive significant influence on the consumer engagement $(\beta=0.38, p<0.05)$, supporting H2. This implies that social media users tend to like those posts which give them pleasure or fun. Visuals with incentive contents also positively influences consumer engagement $(\beta=0.12, p<0.05)$ as the social media users often seek offers on the products, coupons, and discounts on corporate SNS pages. Thus the present study accepts H3. Further, consumer engagement also demonstrated a positive effect on the quality of consumer-brand relationships $(\beta=0.20, p<0.05)$ supporting $\mathrm{H} 4$. This implies that the social media users, who are engaged with corporate SNS pages, feel that they share very good relationship with the company. Moreover, both consuming $(\beta=0.84, p<0.05)$ and contributing $(\beta=0.81, p<0.05)$ were found be strong indicators of the consumer engagement. This implies that the social media user's consuming and contributing activities on corporate SNS pages play an essential role in building strong relationship with the organization/brand in terms of trust, satisfaction and commitment. Further, the proposed conceptual model explained a substantial amount of variance for consumers engagement $\left(R^{2}=.84\right)$ and for consumerbrand relationship $\left(R^{2}=.71\right)$.

\section{Visual Content Types}

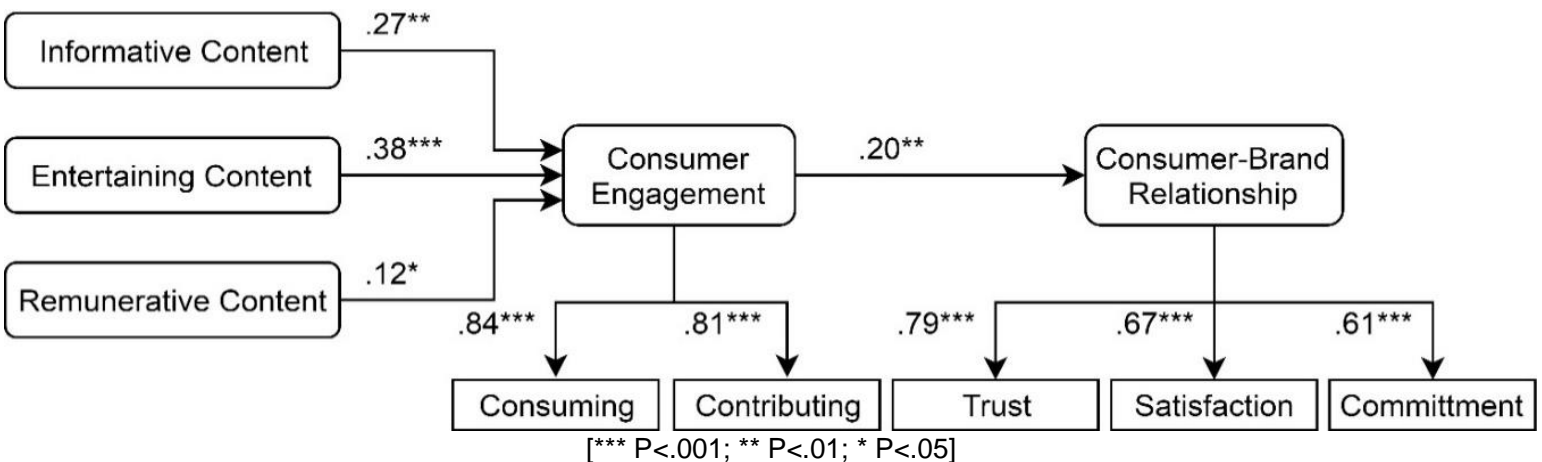

Figure1: SEM results of the proposed model

In addition to it, the present study also checked the indirect effects to test for the mediating effects of consumer engagement. To test the mediation effects between visual contents and consumer-brand relationship, a bias-corrected bootstrapping (5000) sampling procedure with 95 percent confidence interval was applied. Bootstrapping method is based on the study of Preacher and Hayes [101], which is used for testing indirect effects or mediation. This method is also used for controlling Type I error and for data normality and has more statistical power than the three-step approach of mediation test advocated by Baron and Kenny (1986) and the Sobel test Sobel (1982) [40], [73]. To test the mediation effect, the study used PROCESS version 3.0 by Andrew F. Hayes on SPSS. Table 3 summarizes the result of mediation analysis. Although the literature does not show direct relationship of visual contents with consumer-brand relationship, the empirical result of this study showed a significant and positive relationship between them. Entertaining visual content had high influence on consumer-brand relationship $(\beta=0.38, p<0.05)$ followed by informative visual content $(\beta=0.26, p<0.05)$ and incentive visual content $(\beta=0.14, p<0.05)$. Consumer engagement partially mediates the effects of informative content, entertaining content on consumer-brand relationship and fully mediates the effect of incentive content on consumer-brand relationship.

Table 3: Results of mediation analysis

\begin{tabular}{|c|c|c|c|c|c|c|c|}
\hline IV & $\mathrm{M}$ & DV & $\mathrm{IV} \rightarrow \mathrm{DV}$ & $\mathrm{IV} \rightarrow \mathrm{M}$ & \multicolumn{2}{|l|}{$\mathrm{IV}+\mathrm{M} \mathrm{DV}$} & Mediating \\
\hline & & & & & $\mathrm{IV} \rightarrow \mathrm{DV}$ & $\mathrm{M} \rightarrow \mathrm{DV}$ & \\
\hline Informative & $\mathrm{CE}$ & CBR & $.26^{\star *}$ & $.51^{* \star *}$ & $-.18^{* *}$ & $.40^{\star \star *}$ & Partially \\
\hline Entertaining & $\mathrm{CE}$ & CBR & $.38^{* \star *}$ & $.67^{* \star *}$ & $-.21^{* \star}$ & $.49^{\star \star \star}$ & Partially \\
\hline Incentive & CE & CBR & $.14^{*}$ & $.30^{\star \star *}$ & $-.02 N . S$ & $.27^{\star \star \star}$ & Fully \\
\hline
\end{tabular}

Notes: (1) IV- Independent Variable; M- Mediator; DV- Dependent Variable; CE- Consumer Engagement; CBR- Consumer-Brand Relationship. (2) N.S- Non-significant.

$\left[{ }^{* *} \mathrm{P}<.001 ;{ }^{* *} \mathrm{P}<.01 ;{ }^{*} \mathrm{P}<.05\right]$

\section{Discussion}

This study has made an attempt to explore the influences of visuals contents on the level of consumer-brand relationship through consumer engagement using UGT. Based on this theoretical framework, the quality of consumerbrand relationship was tested with the hypothesized relationships. The result of the examined hypothesized relationships shows that visuals have positive impact on the consumer engagement and further helps in establishing consumer-brand relationship. The respondents revealed that visual content types play a major role in their active involvement on the corporate SNS pages in Indian context. Moreover, those users who engage themselves more in 
viewing images and watching videos on the corporate SNS pages tend to create trust towards the company/brand and experience a higher level of satisfaction and develop a sense of commitment toward the organization/brand.

From the analysis, entertaining content was found to be the most influential for the consumer engagement as it was perceived to be fun, exciting, cool, and flashy. Contents with some creative arts draw instant attention that influences the users to view the contents and share it. Entertaining content with small talk also creates an attempt to gain trust and appeals to a person's emotions. Since the entertaining content exerts emotional appeal to the consumers viewing brand-related content, it can strike their subconscious reactions which supersede their logical and pragmatic responses to create the unbreakable bond with a brand. This process further leads to engaging the viewers on a personal leve and helps in gaining more audience retention as compared to informational appeals. The studies of Sheth and Kim [111]; Ashley and Tuten [3] and Luo [82] have also found entertaining content as highly influential in terms of engaging consumers. The companies can use a variety of entertaining and enjoyable content (e.g., riddles and jokes, daily horoscopes, music videos of brand endorsers, and human interest stories) for advertising of their new as well as existing products or services for engaging them in brand-related activities. However, the informative contents are also liked by the users as they intend to seek maximum details about the brand and company. Informative content evokes consumers' desire to stay up-to-date with current events regarding new as well as existing products or services details. In addition to staying updated, people who are information oriented takes benefit of other's knowledge and get inspirations for product usages. Lengthy information often creates a nuisance for the users to skip the contents. Therefore, short information may be recommended for the active consumer engagement so that it can be liked and shared by the most users on corporate SNS pages. Though the present study has found entertaining content highly influential than informative content, but previous studies like Shi et al. [112], Enginkaya and Yılmaz [38]; Park et al. [97] have shown in their studies that informational value drives consumers to interact with brands through social media. The informative content is very much relevant in the case of new products or services since; it gives new knowledge to the consumers regarding brand's details. But once the brand becomes known to the market, the consumers tend to have less interest in it. Further, companies can post different information, facts and other promotional activities, offers, coupons etc., on the brand SNS page regularly in order to gain attention of the users. Companies encourage the visitors to participate in the discussions and debates on the topics that are useful to generate new insights and contents for the company to utilize. This strategy raises the spirits of the consumers to speak positive about the product. Although visuals with incentive, in the present study, has received very low impact on the consumer engagement but it is actually one of the important factor for consumer engagement which further leads to positive attitude and purchase intentions [35]. The probable reason for low impact may be the most of the respondents of this study are students and they are completely depended on their parents for monetary supports. Since they do not have freedom for purchasing, the incentive contents like offers, coupons, discounts etc., might seem to be very less important. Even prior studies like Chua and Banerjee [20] have stated incentive as insignificant relationship with the brand post popularity which includes likes, shares and comments. But a blend of these three visual contents can strike consumers attentions to respond favorably toward the ad stimuli and do influence consumer-brand interaction over corporate SNS pages. Further, the empirical study shows direct, significant and positive impact of visual contents on consumer-brand relationship in social media environment but when consumer engagement is considered as mediator then the effectiveness of visual contents becomes even more on relationship building mechanism. Because when people are engaged with the brand-related content, they begin to develop a meaningful, emotional attachment with the brands via brand SNS pages which ultimately increases the level of trust, feeling of satisfaction and keep them committed to the brands. Since the present study is empirical in nature, it does not focus much on the theoretical contributions. In empirical work, it is always suggested to emphasize more on the practical or managerial implications of the study [1].

While measuring consumer's levels of engagement, the result indicated that respondents were found to be engaged passively with brand SNS pages. This implies consumer's one-way consumption pattern of the content posted on SNS such as watching brand-related videos, viewing brand pictures, reading product's reviews etc. The present result has found comparatively low level of participation in contributing activities like commenting, rating products/brands, engaging in conversations, recommending friends to like and sharing activities in contrast to the previous studies emphasizing that consumers are actively and meaningfully engaged in brand-related activities [90]. Creating activities have high impact on consumer engagement due to higher level of engagement such as writing product reviews, uploading brand related user-generated content, writing articles or web blogs relating to brands etc. However, the respondents of the present study reflected a passive behavior towards it. It suggests to the advertisers that they must understand the importance of not only increasing fan base on brand SNS pages but to engage consumers actively in contributing and creating activities. Rather they should carefully make strategies to motivate consumers to share usergenerated content, including product reviews and product related tips, pictures, and videos. The advertisers should conduct some contests to encourage writing articles and web blogs relating to brands by providing monetary incentives to consumers to get more responses from them. The results also revealed that the deeper engagement levels gradually influences the user's attitude which further leads to the personal involvement and positive word-of-mouth with their friends and relatives. In addition, the respondents who were actively engaged in interpersonal interactions with brand SNS pages, perceived a better relationship with the company. Thus, this interpersonal interaction forms an essential part in reinforcing the strong customer-organization relationships [86].

The results also revealed that the engagement process gradually influenced the user's attitude which leads to the personal involvement and positive word-of-mouth with their friends and relatives. Thus this interpersonal interaction forms an essential part in reinforcing the strong consumer-brand relationships. 


\section{Conclusion}

The rise of social media has provided a new avenue for organizations to develop stronger relationships with their audience. The present study proposes a theoretical model of how visual communications helps in strengthening consumer-brand relationship by engaging people on corporate SNS pages. This paper investigates the extent to which brands utilize visual content and also checks the influence of visual content on the level of engagement received from the audience. To achieve this, the present study analyzed the influence of visual contents (such as informative content, entertaining content and incentive content) identified in the literature, as inducers of engagement in social media, in a particular context of a Facebook. UGT has been adopted as the theoretical foundation of the present study because this theory explains different needs (need for information, need for entertainment and need for incentive) of the people which they gratify or fulfill by using or taking active part with a particular media. The present study explores the people's motive for consuming visual contents of a particular brand on brand SNS pages by engaging themselves actively in it. The results showed that, although all the motivations identified have some relation with engagement, the entertaining content and informative content about a brand were found to be highly influential in terms of engaging people on Facebook brand pages. In addition to that the result showed that people were mostly engaged passively with the brand SNS pages as their consuming activities like watching brand-related videos, viewing brand pictures, reading product's review etc. observed more with visual content. On the other hand, contributing and creating activities relating to brand were observed less as these two activities demand active participation. Further, the paper revealed that more the people are engaged with a particular brand, deeper is the relationship with that brand. The interpersonal interaction with the brand creates a sense of belongingness and strengthens consumer-brand relationship. The present study has considered three dimensions (such as trust, satisfaction, and commitment) which measure the level of consumers' relationship with the brand. From the result it is evident that the process of consumers' engagement with the brand has high influence on the dimension trust, followed by satisfaction and commitment leading to consumer-brand relationship.

\section{Managerial Implications}

The present study has addressed the importance of visual communications in the era of social media which is rising constantly with a pace that has never been witnessed. Visual communication has emerged as the primary way to engage with today's audiences and is used excessively by the corporates to maintain good rapport and better relationship with their stakeholders. Therefore, it becomes very important of the companies to analyze the visual contents so that they can provide right and valuable contents that will motivate consumers to follow or interact with a brand on Facebook/SNSs. The business organizations should focus on the visual content because visuals are easy to understand and are valued more by people. This ultimately provides not only a better consumer-brand engagement on brand SNS pages, but also a better understanding and a strong consumer-brand relationship.

Entertaining content was found to be most influential in terms of engaging the social media users. Therefore, the companies can use a variety of entertaining and enjoyable content (e.g., riddles and jokes, daily horoscopes, music, videos of brand endorsers, human interest stories, games, and interesting applications) for advertising new as well as existing products or services for drawing their valuable attention and engage them in brand-related activities. Nevertheless, informative contents are also mostly liked by the users as they seek more details about the brand and company. Consumers resort to the brand's Facebook page to get information about the products, not only provided by the brand but also provided by other users. The sharing of experiences and giving or receiving product reviews are valued activities by the consumers. Brands should therefore allow and encourage consumers to like, comment and give their opinions. Additionally, brands should have an active role, not only stimulating the participation, but also answering promptly any questions or issues that might emerge. Although visuals with incentive content seems to be less influential in terms of engaging consumers on brand SNS pages, but it is actually an important factor as it is related with monetary terms. The use of incentive content is an easy and cost-effective way to obtain social share for getting the information about brand or product go viral.

\section{Future Research Directions and Limitations}

This study possesses some limitations that deserve further research. First of all, this study has considered only one popular SNS: Facebook. Since, the usage purpose and features of different SNSs are different; the future research should be directed by taking other popular SNSs like Twitter and Linkedln, to gain a broader insight of consumer engagement on other brand SNS pages. Secondly, the present study has stressed on exploring the quality of consumer-brand relationship as the major outcome of visual communication through consumer engagement on brand SNS pages. Therefore, the future study should be directed toward measuring the relationship between visual communication through consumer engagement and other important outcomes, such as brand advocacy behaviors, positive word-of-mouth behaviors, and brand loyalty. Thirdly, the present study has considered types of visual contents to measure consumer-brand relationship through consumer engagement whereas it has ignored the influence of different forms or types of visual communication such as images, videos, info graphs, posters of brand/organization etc., on relationship building. 


\section{References}

[1] P. J. Ågerfalk, Insufficient theoretical contribution: a conclusive rationale for rejection? European Journal of Information Systems, vol. 23, no. 6, pp. 593-599, 2014.

[2] E. W. Anderson, C. Fornell and D. R. Lehmann, Customer satisfaction, market share, and profitability: Findings from Sweden, The Journal of Marketing, vol. 58, no. 3, pp. 53-66, 1994.

[3] C. Ashley and T. Tuten, Creative strategies in social media marketing: An exploratory study of branded social content and consumer engagement, Psychology \& Marketing, vol. 32, no. 1, pp. 15-27, 2015.

[4] A. Aurrichio and C. Zdanowicz, Producing social media engagement through visual content, White Paper, Zdanowicz, Craig, June, 2014.

[5] A. Bardan, Visual framing on the debating Europe platform: A case study on the economic consequences and attribution of responsibility generic frames, Revista Româna de Jurnalism si Comunicare, vol. 11, no. 2/3, pp. 5363, 2016.

[6] A. Bashir, J. Wen, E. Kim, and J. D. Morris, The role of consumer affect on visual social networking sites: How consumers build brand relationships, Journal of Current Issues \& Research in Advertising, vol. 39, no. 2 , pp. 1 $14,2018$.

[7] K. A. Bollen, A new incremental fit index for general structural equation models, Sociological Methods \& Research, vol. 17, no. 3, pp. 303-316, 1989.

[8] R. N. Bolton, A dynamic model of the duration of the customer's relationship with a continuous service provider: The role of satisfaction, Marketing Science, vol. 17, no. 1, pp. 45-65, 1998.

[9] R. N. Bolton, Comment: Customer engagement: Opportunities and challenges for organizations, Journal of Service Research, vol. 14, no. 3, pp. 272-274, 2011.

[10] H. Boomgaarden, M. Boukes and A. lorgoveanu, Image versus text: How newspaper reports affect evaluations of political candidates, International Journal of Communication, vol. 10, pp. 2529-2555, 2016.

[11] D. S. Bortree, Mediating the power of antecedents in public relationships: A pilot study, Public Relations Review, vol. 37, no. 1, pp. 44-49, 2011.

[12] J. L. H. Bowden, The process of customer engagement: A conceptual framework, Journal of Marketing Theory and Practice, vol. 17, no. 1, pp. 63-74, 2009.

[13] R. J. Brodie and L. D. Hollebeek, Advancing and consolidating knowledge about customer engagement, Journal of Service Research, vol. 14, no. 3, pp. 283-284, 2011.

[14] R. Brodie, C. Ilic, B. Juric, and L. Hollebeek, Consumer engagement in a virtual brand community: An exploratory analysis, Journal of Business Research, vol. 66, no. 1, pp. 105-114, 2013.

[15] P. J. Brubaker and C. Wilson, Let's give them something to talk about: Global brands' use of visual content to drive engagement and build relationships, Public Relations Review, vo. 44, no. 3, pp. 342-352, 2018.

[16] M. Chahal. (2017, February) The impact of image-based posts on social media insight. Marketing Week. [Online]. Available: https://www.marketingweek.com/2017/02/22/effect-image-based-posts-social-media-insight/

[17] Y. P. Chang and D. H. Zhu, The role of perceived social capital and flow experience in building users' continuance intention to social networking sites in China, Computers in Human Behavior, vol. 28, pp. 995-1001, 2012.

[18] J. M. S. Cheng, C. Blankson, E. S. T. Wang, and L. S. L. Chen, Consumer attitudes and interactive digital advertising, International Journal of Advertising, vol. 28, no. 3, pp. 501-525, 2009.

[19] S. C. Chu, Viral advertising in social media: Participation in Facebook groups and responses among college-aged users, Journal of interactive advertising, vol. 12, no. 1, pp. 30-43, 2011.

[20] A. Y. Chua and S. Banerjee, How businesses draw attention on Facebook through incentives, vividness and interactivity, IAENG International Journal of Computer Science, vol. 42, no. 3, pp. 275-81, 2015.

[21] G. Clavio and P. Walsh, Dimensions of social media utilization among college sport fans, Communication \& Sport, vol. 2, no. 3, pp. 261-281, 2014.

[22] B. Cooper. (2016, April) How twitter's expanded images increase clicks, retweets and favorites. Buffer. [Online] Available: https://blog.bufferapp.com/the-power-of-twitters-new-expanded-images-and-how-to-make-the-mostof-it

[23] P. Cvijikj and F. Michahelles, Online engagement factors on Facebook brand pages, Social Network Analysis and Mining, vol. 3, no. 4, pp. 843-861, 2013.

[24] M. J. De Oliveira, M. K. Z. Huertas and Z. Lin, Factors driving young users' engagement with Facebook: Evidence from Brazil, Computers in Human Behavior, vol. 54, pp. 54-61, 2016.

[25] L. De Vries, S. Gensler and P. S. Leeflang, Popularity of brand posts on brand fan pages: An investigation of the effects of social media marketing, Journal of Interactive Marketing, vol. 26, no. 2, pp. 83-91, 2012.

[26] L. De Vries, A. M. Peluso, S. Romani, P. S. Leeflang, and A. Marcati, Explaining consumer brand-related activities on social media: An investigation of the different roles of self-expression and socializing motivations, Computers in Human Behavior, vol. 75, pp. 272-282, 2017.

[27] N. J. De Vries and J. Carlson, Examining the drivers and brand performance implications of customer engagement with brands in the social media environment, Journal of Brand Management, vol. 21, no. 6, pp. 495-515, 2014.

[28] M. Dehghani and M. Tumer, A research on effectiveness of Facebook advertising on enhancing purchase intention of consumers, Computers in Human Behavior, vol. 49, pp. 597-600, 2015.

[29] L. Dessart, Social media engagement: a model of antecedents and relational outcomes, Journal of Marketing Management, vol. 33, no. 5-6, pp. 375-399, 2017. 
[30] L. Dessart, C. Veloutsou and A. Morgan-Thomas, Consumer engagement in online brand communities: a social media perspective, Journal of Product \& Brand Management, vol. 24, no. 1, pp. 28-42, 2015.

[31] U. M. Dholakia, R. P. Bagozzi and L. K. Pearo, A social influence model of consumer participation in network-and small-group-based virtual communities, International journal of research in marketing, vol. 21, no. 3, pp. 241-263, 2004

[32] N. Dlodlo and N. Dhurup, Examining social media dimensions among a cohort of generation y consumers in South Africa, Mediterranean Journal of Social Sciences, vol. 4, no. 14, pp. 329-338, 2013

[33] R. Dolan, J. Conduit, J Fahy, and S. Goodman, Social media engagement behaviour: A uses and gratifications perspective, Journal of Strategic Marketing, vol. 24, no. 3-4, pp. 261-277, 2016.

[34] A. Dovaliene, A. Masiulyte and Z. Piligrimiene, The relations between customer engagement, perceived value and satisfaction: The case of mobile applications, Procedia-Social and Behavioral Sciences, vol. 213, pp. 659664,2015

[35] D. Drossos, G. M. Giaglis, G. Lekakos, F. Kokkinaki, and M. G. Stavraki, Determinants of effective SMS advertising: An experimental study, Journal of Interactive Advertising, vol. 7, no. 2, pp. 16-27, 2007.

[36] R. G. Duffett, The influence of Facebook advertising on cognitive attitudes amid generation Y, Electronic Commerce Research, vol. 15, no. 2, pp. 243-267, 2015.

[37] J. Egan, Relationship Marketing: Exploring Relational Strategies in Marketing (4th Ed.). Harlow: Financial Times Prentice Hall, (Part 1), 2011.

[38] E. Enginkaya and H. Yılmaz, What drives consumers to interact with brands through social media? A motivation scale development study, Procedia-Social and Behavioral Sciences, vol. 148, pp. 219-226, 2014.

[39] S. Fahmy, M. A. Bock and W. Wanta, With What Effect III: Research on Behavioral Effects of Visual Communication. In Visual Communication Theory and Research. New York: Palgrave Macmillan, 2014.

[40] A. J. Fairchild and S. D. McQuillin, Evaluating mediation and moderation effects in school psychology: A presentation of methods and review of current practice, Journal of School Psychology, vol. 48, no. 1, pp. 53-84, 2010.

[41] A. Ferrand and S. McCarthy, Marketing the sports organization: building networks and relationships. Routledge, 2009

[42] M. Ferreira and F. Zambaldi, The Mediating Role of Consumer Engagement with the Brand Community and Its Effect on Corporate Reputation, International Journal on Media Management, vol. 21, no. 1, pp. 45-64, 2019.

[43] Y. Gao and M. Koufaris, Perceptual antecedents of user attitude in electronic commerce, AcmSigmis Database, vol. 37, no. 2-3, pp. 42-50, 2006.

[44] E. Garbarino and M. S. Johnson, The different roles of satisfaction, trust, and commitment in customer relationships, The Journal of Marketing, vol. 63, no. 2, pp. 70-87, 1999.

[45] K. Göransson and A-S. Fagerholm, Towards visual strategic communications: An innovative interdisciplinary perspective on visual dimensions within the strategic communications field, Journal of Communication Management, vol. 22, no. 1, pp. 46-66, 2018.

[46] A. Grunig, J. E. Grunig and W. P. Ehling, What is an effective organization? in Excellence in Public relations and Communication Management (J. E. Grunig, Ed.). Hillsdale, NJ: Lawrence Erlbaum Associates, 1992, pp. 65-90.

[47] J. Gummerus, V, Liljander, E. Weman, and M. Pihlström, Customer engagement in a Facebook brand community, Management Research Review, vol. 35, no. 9, pp. 857-877, 2012.

[48] E. Gummesson, Total relationship marketing: experimenting with a synthesis of research frontiers, Australasian Marketing Journal, vol. 7, no. 1, pp. 72-85, 1999.

[49] Z. Hadija, S. B. Barnes and N. Hair, Why we ignore social networking advertising, Qualitative Market Research: An International Journal, vol. 15, no. 1, pp. 19-32, 2012.

[50] M. Haigh, P. Brubaker and E. Whiteside, Facebook: Examining the information presented and its impact on stakeholders, Corporate Communications: An International Journal, vol. 18, no. 1, pp. 52-69, 2013.

[51] J. F. Hair Jr, W. C. Black, B. J. Babin, R. E. Anderson, and R. L. Tatham, SEM: An introduction. Multivariate Data Analysis: A Global Perspective. 7th edn. Upper Saddle River: Pearson Prentice Hall, 2010.

[52] M. Hellberg, Visual brand communication on Instagram: A study on consumer engagement, Ph.D. dissertation, Hanken School of Economics, Helsinki, 2015.

[53] T. Hennig-Thurau, E. C. Malthouse, C. Friege, S. Gensler, L. Lobschat, A. Rangaswamy, and B. Skiera, The impact of new media on customer relationships, Journal of service research, vol. 13, no. 3, pp. 311-330, 2010.

[54] H. Herzog, What do we really know about day-time serial listeners? in Radio Research (P. F. Lazarsfeld and F. K. N. Stanton, Eds.). New York: Duel, Sloan and Pearce, 1944, pp. 3-33.

[55] E. T. Higgins and A. A. Scholer, Engaging the consumer: The science and art of the value creation process, Journal of Consumer Psychology, vol. 19, no. 2, pp. 100-114, 2009.

[56] J. Y. Ho and M. Dempsey, Viral marketing: Motivations to forward online content, Journal of Business Research, vol. 63, no. 9, pp. 1000-1006, 2010.

[57] L. Hollebeek, Exploring customer brand engagement: Definition and themes, Journal of Strategic Marketing, vol. 19, no. 7, pp. 555-573, 2011.

[58] L. D. Hollebeek, J. Conduit and R. J. Brodie, Strategic drivers, anticipated and unanticipated outcomes of customer engagement, Journal of Marketing Management, vol. 32, no. 5-6, pp. 393-398, 2016.

[59] L. D. Hollebeek, M. S. Glynn and R. J. Brodie, Consumer brand engagement in social media: Conceptualization, scale development and validation, Journal of Interactive Marketing, vol. 28, no. 2, pp. 149-165, 2014

[60] L. C. Hon and J. E. Grunig, Guidelines for Measuring Relationships in Public Relations. Gainesville, FL: The Institute for Public Relations, University of Florida, 1999. 
[61] S. H. Hsieh and A. Chang, The psychological mechanism of brand co-creation engagement, Journal of Interactive Marketing, vol. 33, pp. 13-26, 2016.

[62] M. Husnain and A. Toor, The impact of social network marketing on consumer purchase intention in Pakistan: Consumer Engagement as a Mediator, Asian Journal of Business and Accounting, vol. 10, no. 1, pp. 167-199, 2017.

[63] M. Husnain, I. Qureshi, T. Fatima, and W. Akhtar, The impact of electronic word-of-mouth on online impulse buying behavior: The moderating role of Big 5 personality traits, Journal of Accounting \& Marketing, vol. 5, no. 190, pp. 1-10, 2016.

[64] D. Jakus, Visual communication in public relations campaigns, Marketing of Scientific and Research Organizations, vol. 27, no. 1, pp. 25-36, 2018.

[65] Y. Jordaan, L. Ehlers and J. M. Grove, Advertising credibility across media channels: Perceptions of generation Y consumers, Communicare, vol. 30, no. 1, pp, 1-20, 2011.

[66] M. L. Kent and M. Taylor, Toward a dialogic theory of public relations, Public Relations Review, vol. 28, pp. 21 37, 2002.

[67] M. L. Khan, Social media engagement: What motivates user participation and consumption on YouTube? Computers in Human Behavior, vol. 66, pp. 236-247, 2017

[68] S. Khan. (2016, March), Facebook reaches 142M users in India, crosses 100M users for 'Lite' app globally, international business times. International Business Times. [Online]. Available: http://www.ibtimes.co.in/facebookreaches-142m-users-india-crosses-100m-users-lite-app-globally-670276

[69] C. Kim and S. U. Yang, Like, comment, and share on Facebook: How each behavior differs from the other, Public Relations Review, vol. 43, no. 2, pp. 441-449, 2017.

[70] D. Kimball. (2015, May). The importance of visuals in social media. Re:group. [Online]. Available: http://regroup.us/2015/blog/advertising/the-importance-of-visuals-in-social-media

[71] F. Kujur and S. Singh, Social networking sites as a multimedia tool for brand popularity-an exploratory study, Indian Journal of Science and Technology, vol. 9, no. 45, pp. 1-7, 2016

[72] F. Kujur and S. Singh, Engaging customers through online participation in social networking sites, Asia Pacific Management Review, vol. 22, no. 1, pp. 16-24, 2017.

[73] R. S. Lau and G. W. Cheung, Estimating and comparing specific mediation effects in complex latent variable models, Organizational Research Methods, vol. 15, no. 1, pp. 3-16, 2012

[74] J. A. Ledingham and S. D. Bruning, Relationship management in public relations: Dimensions of an organizationpublic relationship, Public Relations Review, vol. 24, pp. 55-65, 1998

[75] S. Lee and L. Ma, News sharing in social media: The effect of gratifications and prior experience, Computers in Human Behavior, vol. 28, no. 2, pp. 331-339, 2012.

[76] T. Li and Z. Meshkova, Examining the impact of rich media on consumer willingness to pay in online stores, Electronic Commerce Research and Applications, vol. 12, no. 6, pp. 449-461, 2013.

[77] H. Lien and Y. Cao, Examining WeChat users' motivations, trust, attitudes, and positive word-of-mouth: Evidence from China, Computers in Human Behavior, vol. 41, pp. 104-111, 2014

[78] W. M. Lim and D. H. Ting, E-shopping: An analysis of the uses and gratifications theory, Modern Applied Science, vol. 6, no. 5, pp. 48-63, 2012.

[79] K. Lin and H. Lu, Why people use social networking sites: An empirical study integrating network externalities and motivation theory, Computers in Human Behavior, vol. 27, no. 3, pp. 1152- 1161, 2011.

[80] P. Luarn, Y. F. Lin and Y. P. Chiu, Influence of Facebook brand-page posts on online engagement, Online Information Review, vol. 39, no. 4, pp. 505-519, 2015.

[81] P. Luarn, J. C. Yang and Y. P. Chiu, Why people check in to social network sites, International Journal of Electronic Commerce, vol. 19, no. 4, pp. 21-46, 2015

[82] X. Luo, Uses and gratifications theory and e-consumer behaviors: a structural equation modeling study, Journa of Interactive Advertising, vol. 2, no. 2, pp. 34-41, 2002.

[83] J. Malciute amd P. Chrysochou, Customer brand engagement on online social media platforms: A conceptua model and empirical analysis, Unpublished M.S. thesis, Aarhus University, Aarhus, 2012.

[84] C. Malthouse, M. Haenlein, B. Skiera, E. Wege, and M. Zhang, Managing customer relationships in the socia media era: Introducing the social CRM house, Journal of Interactive Marketing, vol. 27, no. 4, pp. 270-280, 2013.

[85] M. Manic, Marketing engagement through visual content, Bulletin of the Transilvania University of Brasov, Economic Sciences. Series V, vol. 8, no. 2, p. 89, 2015.

[86] L. R. Men and W. H. S. Tsai, Toward an integrated model of public engagement on corporate social networking sites: Antecedents, the process, and relational outcomes, International Journal of Strategic Communication, vol. 7, no. 4, pp. 257-273, 2013.

[87] L. R. Men and W. H. S. Tsai, Perceptual, attitudinal, and behavioral outcomes of organization-public engagement on corporate social networking sites, Journal of Public Relations Research, vol. 26, no. 5, pp. 417-435, 2014.

[88] T. More. (2014, September), Why visual content is crucial to customer engagement. Salesforce. [Online]. Available: https://www.salesforce.com/blog/2014/09/visual-content-customer-engagement-gp.htm/

[89] L. Muñoz and T. L. Towner, The image is the message: Instagram marketing and the 2016 presidential primary season, Journal of Political Marketing, vol. 16, no. 3-4, pp. 290-318, 2017.

[90] G. Muntinga, M. Moorman and E. G. Smit, Introducing COBRAs: Exploring motivations for brand-related socia media use, International Journal of Advertising, vol. 30, no. 1, pp. 13-46, 2011.

[91] S. S. Nammir, B. M. Marane and A. M. Ali, Determine the role of customer engagement on relationship quality and relationship performance. European Journal of Business and Management, vol. 4, no. 11, pp. 27-36, 2012. 
[92] K. Neher (2014), Visual social marketing for dummies. Part I: Getting started with visual social marketing. Chapter 1: Marketing in the age of visual content. Wileyndia. [Online]. Available: https://www.wileyindia.com/media/ pdf/1118753488-58.pdf

[93] M. Ng, Factors influencing the consumer adoption of Facebook: A two-country study of youth markets. Computers in Human Behavior, vol. 54, pp. 491-500, 2016.

[94] W. Ngai, S. S. Tao and K. K. Moon, Social media research: Theories, constructs, and conceptual frameworks, International Journal of Information Management, vol. 35, no. 1, pp. 33-44, 2015.

[95] C. Oh, Y. Roumani, J. K. Nwankpa, and H. F. Hu, Beyond likes and tweets: Consumer engagement behavior and movie box office in social media, Information \& Management, vol. 54, no. 1, pp. 25-37, 2017.

[96] M. Pandey and A. C. Y. Sang, Capturing the visual language of social media, in Proceedings 2015 IEEE International Conference on Multimedia and Expo (ICME), Torino, Italy, 2015, pp. 1-6.

[97] N. Park, K. F. Kee and S. Valenzuela, Being immersed in social networking environment: Facebook groups, uses and gratifications, and social outcomes, Cyber Psychology \& Behavior, vol. 12, no. 6, pp. 729-733, 2009.

[98] C. Pavel. (2014, april) Using visual content in your marketing. QUAESTUS Multidisciplinary Research Journal [Online]. Available: http://www.quaestus.ro/wp-content/uploads/2012/03/pavel5.pdf

[99] G. Pereira, M. de FátimaSalgueiro and I. Mateus, Say yes to Facebook and get your customers involved! Relationships in a world of social networks, Business Horizons, vol. 57, no. 6, pp. 695-702, 2014.

[100] C. Pollard, (2017, December). Why visual content is a social media secret weapon. Huffpost. [Online]. Available: https://www.huffingtonpost.com/catriona-pollard/why-visual-content-is-a-s b 7261876.html

[101]K. J. Preacher and A. F. Hayes, SPSS and SAS procedures for estimating indirect effects in simple mediation models, Behavior research methods, Instruments, \& Computers, vol. 36, no. 4, pp. 717-731, 2004

[102]A. Raney and S. H. Janicke, How we enjoy and why we seek out morally complex characters in media entertainment, in Media and the Moral Mind (R. Tamborini, Ed.). London: Routledge, 2013, pp. 152-170.

[103] L. Safko and D. K. Brake, The Social Media Bible-Tactics. Hoboken, New Jersey: Tools \& for Business Success. 2009.

[104] C. M. Sashi, Customer engagement, buyer-seller relationships, and social media, Management decision, vol. 50 , no. 2, pp. 253-272, 2012

[105]A. Saxena and U. Khanna, Advertising on social network sites: A structural equation modeling approach, Vision, vol. 17, no. 1, pp. 17-25, 2013.

[106]J. Schamari and T. Schaefers, Embedding Consumers-Mediation of Social Media Engagement Effects on Consumerbrand Relationships, Ideas in Marketing: Finding the New and Polishing the Old. Cham: Springer, 2015.

[107]B. Schivinski, G. Christodoulides and D. Dabrowski, A scale to measure consumer's engagement with socia media brand-related content, in Proceedings of the 14th International Conference on Research in Advertising ICORIA, At London, UK, 2015, pp. 1-8.

[108]M. Schreiber, Showing/sharing: Analyzing visual communication from a praxeological perspective, Media and Communication, vol. 5, no. 4, pp. 37-50, 2017.

[109]G. Shao, Understanding the appeal of user-generated media: a uses and gratification perspective, Internet Research, vol. 19, no. 1, pp. 7-25, 2009

[110]A. Sharma, A. Bhosle and B. Chaudhary, Consumer perception and attitude towards the visual elements in social campaign advertisement, IOSR Journal of Business and Management (IOSRJBM), vol. 3, no. 1, pp. 6-17, 2012.

[111]S. Sheth and J. Kim, Social media marketing: The effect of information sharing, entertainment, emotional connection and peer pressure on the attitude and purchase intentions, GSTF Journal on Business Review (GBR), vol. 5, no. 1, pp. 62-70, 2018.

[112] S. Shi, Y. Chen and W. S. Chow, Key values driving continued interaction on brand pages in social media: An examination across genders, Computers in Human Behavior, vol. 62, pp. 578-589, 2016.

[113]B. A. Nedra, W. Hadhri and M. Mezrani, Determinants of customers' intentions to use hedonic networks: The case of Instagram, Journal of Retailing and Consumer Services, vol. 46, pp. 21-32, 2019.

[114] A. D. Smock, N. B. Ellison, C. Lampe, and D. Y. Wohn, Facebook as a toolkit: A uses and gratification approach to unbundling feature use, Computers in Human Behavior, vol. 27, no. 6, pp. 2322-2329, 2011

[115]M. Song, N. Wang, X. Zhang and L. Qiao, Factors motivating customers' SNS brand page behaviors: A comparison between China and Korea, Pacific Asia Journal of the Association for Information Systems, vol. 9, no. 4, pp. 25-50, 2018.

[116] A. M. Sundjaja, F. L. Gaol, S. B. Abdinagoro, and B. S. Abbas, The behavior of online museum visitors on Facebook fan page of the museum in Indonesia, Binus Business Review, vol. 8, no. 3, pp. 237-243, 2017.

[117]J. Svensson and U. Russmann, Introduction to visual communication in the age of social media: Conceptual, theoretical and methodological challenges, Media and Communication, vol. 5, no. 4, pp. 1-5, 2017.

[118]W. B. Swann Jr. and M. J. Gill, Confidence and accuracy in person perception: Do we know what we think we know about our relationship partners? Journal of Personality and Social Psychology, vol. 73, no. 4, pp. 747-757, 1997.

[119]W. Tafesse, Content strategies and audience response on Facebook brand pages, Marketing Intelligence \& Planning, vol. 33, no. 6, pp. 927-943, 2015.

[120]D. G. Taylor, J. E. Lewin and D. Strutton, Friends, fans, and followers: do ads work on social networks? Journal of Advertising Research, vol. 51, no. 1, pp. 258-275, 2011

[121]W. H. S. Tsai and L. R. Men, Motivations and antecedents of consumer engagement with brand pages on social networking sites, Journal of Interactive Advertising, vol. 13, no. 2, pp. 76-87, 2013.

[122] W. H. S. Tsai and L. R. Men, Consumer engagement with brands on social network sites: A cross-cultural comparison of China and the USA, Journal of Marketing Communications, vol. 23, no. 1, pp. 2-21, 2014. 
[123] W. Ulaga and A. Eggert, Value-based differentiation in business relationships: Gaining and sustaining key supplier status, Journal of Marketing, vol. 70, no. 1, pp. 119-136, 2006.

[124]J. Van Doorn, K. N. Lemon, V. Mittal, S. Nass, D. Pick, P. Pirner, and P. C. Verhoef, Customer engagement behavior: Theoretical foundations and research directions, Journal of Service Research, vol. 13, no, 3, pp. 253266, 2010.

[125] C. Verhoef, P. H. Franses and J. C. Hoekstra, The effect of relational constructs on customer referrals and number of services purchased from a multiservice provider: does age of relationship matter? Journal of the Academy of Marketing Science, vol.30, no. 3, pp. 202-216, 2002.

[126] V. K. Verma, B. Chandra and S. Kumar, Values and ascribed responsibility to predict consumers' attitude and concern towards green hotel visit intention, Journal of Business Research, vol. 96, pp. 206-216, 2019.

[127]D. Vivek, S. E. Beatty and R. M. Morgan, Customer engagement: Exploring customer relationships beyond purchase, Journal of Marketing Theory and Practice, vol. 20, no. 2, pp. 122-146, 2012.

[128] M. H. Wang, T. Y. Yang and Y. S. Chen, How workers engage in social networking sites at work: A uses and gratification expectancy perspective, International Journal of Organizational Innovation (Online), vol. 8, no. 4, pp. 161-176, 2016

[129]X. Wang, B. F. French and P. F. Clay, Convergent and discriminant validity with formative measurement: A mediator perspective, Journal of Modern Applied Statistical Methods, vol. 14, no. 1, pp. 83-106, 2015.

[130]D. Wolin, P. Korgaonkar and D. Lund, Beliefs, attitudes and behaviour towards web advertising, International Journal of Advertising, vol. 21, no. 1, pp. 87-113, 2002.

[131] L. Wu, Understanding the impact of media engagement on the perceived value and acceptance of advertising within mobile social networks, Journal of Interactive Advertising, vol. 16, no. 1, pp. 59-73, 2016.

[132] V. A. Zeithaml, L. L. Berry and A. Parasuraman, The behavioral consequences of service quality, The Journal of Marketing, vol. 60, no. 2, pp. 31-46, 1996.

[133]X. Zheng, C. M. Cheung, M. K. Lee, and L. Liang, Building brand loyalty through user engagement in online brand communities in social networking sites, Information Technology \& People, vol. 28, no. 1, pp. 90-106, 2015. 